\title{
Trametes meyenii possesses elevated dye degradation abilities under normal nutritional conditions compared to other white rot fungi
}

\author{
Peter R Chenaux, Narisa Lalji and Daniel D Lefebvre*
}

\begin{abstract}
Several species of white-rot fungi were investigated for their utility in prolonged decolouration of the recalcitrant sulfonated azo dye, amaranth. Trametes pubescens, T. multicolor, T. meyenii and T. versicolor decoloured amaranth azo-dye best on low-nitrogen agar-solidified media whereas Bjerkandera adusta and Phlebia radiata were most effective in low nitrogen medium supplemented with manganese. Trametes cotonea did not decolour effectively under any condition. The decolouring Trametes species were also effective in liquid culture whereas B. adusta and $P$. radiata were not. Trametes meyenii, T. pubescens and T. multicolor were equal to or better than commonly employed T. versicolor at decolouring amaranth. This is the first study to show the dye decolouration potential of T. meyenii, T. pubescens, and T. multicolor. Supplementing with $\mathrm{Mn}(\mathrm{II})$ increased assayable manganese peroxidase activity, but not long-term decolouration, indicating that laccase is the main decolourizing enzyme in these Trametes species. This appears to be because of inadequate $\mathrm{Mn}^{3+}$ chelation required by manganese peroxidase because adding relatively low amounts of malonate enhanced decolouration rates. The ability of Trametes meyenii to simultaneously decolour dye over prolonged periods of time while growing in relatively nutrient-rich medium appears to be unique amongst white-rot fungi, indicating its potential in wastewater bioremediation.
\end{abstract}

Keywords: White-rot fungi; Dye decolouration; Trametes; Laccase; Manganese peroxidase; Manganic chelation

\section{Introduction}

One of the largest sources of environmental pollutants is the textile industry, which can produce over 800 kilo tonnes of dye annually, with $90 \%$ of the waste discharged into the environment (Nigam et al. 2000; Hessel et al. 2007; Martin et al. 2012). The strong structural integrity and toxic nature of dyes poses risk to flora, fauna and human populations (Chagas and Durrant 2001). The four main chromophoric groups include azo, anthraquinone, triarylmethane and phthalocyanine, with azo dyes accounting for over 50\% used in the textile industry (Heinfling et al. 1998a; Reddy and Mathew 2001). Azo dyes are generally also the most difficult to degrade (Toh et al. 2003; Dafale et al. 2010). Amaranth, a sulfonated compound, was employed as a recalcitrant azo dye in this study.

White-rot fungi are able to degrade lignin, a complex plant biopolymer (Evans and Hedger 2001). They employ relatively non-specific enzymes that are also able to

* Correspondence: lefebvre@queensu.ca

Department of Biology, Queen's University, Kingston, ON K7L 3 N6, Canada attack a wide range of pollutants including textile dyes (Archibald et al. 1997; Van Aken et al. 1999; Pointing 2001; Ramsay and Goode 2004). Even though Trametes versicolor (Swamy and Ramsay 1999b) and some other white-rot fungi (Heinfling et al. 1998b; Levin et al. 2002) do produce these enzymes under nutrient-rich conditions, it is generally accepted that effective degradation occurs during the induction of secondary metabolism only when carbon or nitrogen supplies are low (Archibald et al. 1997; Kaal et al. 1995; Swamy and Ramsay 1999a; Hatvani and Mécs 2002). It would, however, be more desirable from a bioremediation perspective to utilize well nourished growing organisms to decolor dyes for prolonged periods of time.

Manganese peroxidase ( $\mathrm{MnP})$ is the most common ligninolytic peroxidase as it is produced by almost all white-rot basidiomycetes (Morgenstern et al. 2008; Tomsovsky et al. 2009), and laccase occurs in almost all wood- and littertransforming basidiomycetes (Wesenberg et al. 2003). These enzymes play major roles in decolorization processes 
in the fungal genus Trametes where they can be expressed to some degree under primary as well as secondary metabolism (Libra et al. 2003). They are also the main lignin modifying enzymes produced by T. versicolor during decoloration of amaranth dye (Swamy and Ramsay 1999b; Champagne and Ramsay 2005). Although laccase activity predominates under well nourished conditions, it may not be able to decolorize dye in the absence of MnP (Wesenberg et al. 2003; Viswanath et al. 2014). Because of their common occurence and enzyme efficiencies (Morgenstern et al. 2008; Wesenberg et al. 2003; Tomsovsky et al. 2009) and the fact that normal culture conditions for fungi do not induce lignin peroxidase activity (Swamy and Ramsay 1999b), enzyme investigations were limited to $\mathrm{MnP}$ and laccase in this study.

Although there have been several studies on dye degradation by $T$. versicolor, many of the estimated fifty Trametes species (Kirk et al. 2009) have not been investigated. This provides a large resource within which to search for species with desireable bioremediation properties. In the current study we investigate white-rot fungal species, including five species of Trametes, to determine how well they degrade amaranth and produce $\mathrm{MnP}$ and laccase in response to different nutritional treatments. Notable species of the genus Trametes were distinguished by their ability to effectively degrade dye over extended periods of time, and to do so, Trametes meyenii in particular, did not require nutrient deprivation.

\section{Materials and methods}

\section{Culture maintenance and media}

Seven species of fungi (Table 1) were maintained as stocks in $100 \times 15 \mathrm{~mm}$ petri plates containing $15 \mathrm{~mL}$ of modified Kirk's medium (Kirk and Fenn 1982) with 3\% (w:v) malt agar at $4^{\circ} \mathrm{C}$ and $\mathrm{pH}$ 5.0. The modified Kirk's medium consisted of $10 \mathrm{~g} \mathrm{~L}^{-1}$ glucose, $1.2 \mathrm{~g} \mathrm{~L}^{-1}$ ammonium tartrate, $0.05 \mathrm{~g} \mathrm{~L}^{-1} \mathrm{MgSO}_{4} .7 \mathrm{H}_{2} \mathrm{O}, 0.01 \mathrm{~g} \mathrm{~L}^{-1} \mathrm{CaCl}_{2} .2 \mathrm{H}_{2} \mathrm{O}, 0.20 \mathrm{~g} \mathrm{~L}^{-1}$ $\mathrm{K}_{2} \mathrm{HPO}_{4}, 1 \mu \mathrm{g} \mathrm{L}{ }^{-1}$ thiamine, $1 \mathrm{~mL} \mathrm{~L}^{-1}$ trace mineral solution and $15 \mathrm{~g} \mathrm{~L}^{-1}$ agar. The trace mineral solution

Table 1 White-rot fungal strains

\begin{tabular}{|c|c|}
\hline Species & Strain code \\
\hline Bjerkandera adusta & ATCC $^{a}$ MYA-264 \\
\hline Phlebia radiata & ATCC 64658 \\
\hline Trametes cotonea & $\mathrm{CBS}^{\mathrm{b}} 352.80$ \\
\hline Trametes meyenii & CBS 453.76 \\
\hline Trametes multicolor & VIAM $^{c}$ MB 49 \\
\hline Trametes pubescens & CBS 396.90 \\
\hline Trametes versicolor & ATCC 20869 \\
\hline
\end{tabular}

${ }^{a}$ ATCC, American Type Culture Collection, Manassas, USA;

${ }^{\mathrm{b}} \mathrm{CBS}$, Centraalbureau voor Schimmelcultures, Utrecht, The Netherlands;

'VIAM, Culture Collection of the Institute of Applied Microbiology, University of Agricultural Sciences, Vienna, Austria. contained $1 \mathrm{~g} \mathrm{~L}^{-1} \mathrm{NaCl}, 0.5 \mathrm{~g} \mathrm{~L}^{-1} \mathrm{MnSO}_{4} \cdot \mathrm{H}_{2} 0,0.1 \mathrm{~g} \mathrm{~L}^{-1}$ $\mathrm{CoSO}_{4}, 0.1 \mathrm{~g} \mathrm{~L}^{-1} \mathrm{FeSO}_{4} .7 \mathrm{H}_{2} \mathrm{O}, 0.1 \mathrm{~g} \mathrm{~L}^{-1} \mathrm{ZnSO}_{4} .7 \mathrm{H}_{2} \mathrm{O}$, $82 \mathrm{mg} \mathrm{L}^{-1} \mathrm{CaCl}_{2}, 10 \mathrm{mg} \mathrm{L}^{-1} \mathrm{CuSO}_{4} .5 \mathrm{H}_{2} \mathrm{O}, 10 \mathrm{mg} \mathrm{L}^{-1}$ $\mathrm{NaMoO}_{4} \cdot 2 \mathrm{H}_{2} \mathrm{O}, 10 \mathrm{mg} \mathrm{L}^{-1} \mathrm{H}_{3} \mathrm{BO}_{3}$, and $0.1 \mathrm{~g} \mathrm{~L}^{-1}$ ethylene diamine tetraacetic acid at $\mathrm{pH}$ 5.0.

Influence of culture parameters on growth and amaranth decoloration on agar-solidified media

Circular plugs measuring $0.5 \mathrm{~cm}$ diam. were taken from stock plates using the wide end of a sterilized $200 \mu \mathrm{L}$ pipet tip (Advantech AD200Y-K, Diamed Lab Supplies Inc., Mississauga, Canada) and placed in the center of fresh plates and grown at $28^{\circ} \mathrm{C}$. After 4 days fresh plugs were placed on experimental media shown in Table 2. Amaranth was added at $50 \mathrm{ppm}(83 \mu \mathrm{M})$ unless otherwise stated. Plates were kept at $28^{\circ} \mathrm{C}$ and fungal growth and dye decoloration, where appropriate, were measured daily until either fungal growth or decoloration reached the edge of the plate. Growth and decolored zones were determined by measuring their areas on the plates. Experiments were performed in octuplicate.

Influence of culture parameters on amaranth decoloration and enzyme activity in liquid media

Ten $0.5 \mathrm{~cm}$ diameter circular agar plugs from 4 day old petri plate cultures were added to each $500 \mathrm{~mL}$ Erlenmeyer flask containing $100 \mathrm{~mL}$ of Kirk's medium. These were grown at $28^{\circ} \mathrm{C}$ with rotary shaking at $100 \mathrm{rpm}$. The Kirk's medium used followed the same recipe as for the agarsolidified medium without the agar and supplementation with $20 \mathrm{mM}$ 2,2-dimethylsuccinate to act as a buffer (Swamy and Ramsay 1999a). Amaranth treatment was performed as follows. After 5 days the medium was decanted and the fungal pellets were resuspended in $100 \mathrm{~mL}$ of fresh Kirk's medium containing $0.12 \mathrm{mM}$ ammonia tartrate (low-N medium) and $83 \mu \mathrm{M}(50 \mathrm{ppm})$ amaranth. After 4 days, this medium was replaced with that of the same composition and samples were taken at increasing time intervals to determine decoloration of amaranth and enzyme activities. Where appropriate, the effect of $\mathrm{Mn}$ was by the addition of $200 \mu \mathrm{M} \mathrm{MnSO}{ }_{4} \cdot \mathrm{H}_{2} \mathrm{O}$. All

Table 2 Modifications made to standard Kirk's medium

\begin{tabular}{ll}
\hline Medium & Details \\
\hline $\begin{array}{l}\text { Low-N Kirk's } \\
(1.2 \mathrm{mM})\end{array}$ & Basic Kirk's containing $0.22 \mathrm{~g} \mathrm{~L}^{-1}$ ammonium tartrate. \\
$\begin{array}{l}\text { High-N Kirk's } \\
(12 \mathrm{mM})\end{array}$ & Basic Kirk's containing $2.2 \mathrm{~g} \mathrm{~L}^{-1}$ ammonium tartrate. \\
Low-Glu Kirk's & Basic Kirk's containing $1 \mathrm{~g} \mathrm{~L}^{-1}$ glucose. \\
Low-N/Low-Glu & Basic Kirk's containing $1 \mathrm{~g} \mathrm{~L}^{-1}$ glucose \& $0.22 \mathrm{~g} \mathrm{~L}^{-1}$ \\
Kirk's & ammonium tartrate. \\
Low-N Kirk's + & Basic Kirk's containing $0.22 \mathrm{~g} \mathrm{~L}^{-1}$ ammonium tartrate \\
$200 \mu \mathrm{M} \mathrm{Mn}(\mathrm{II})$ & $\& 0.034 \mathrm{~g} \mathrm{~L}^{-1} \mathrm{MnSO}_{4} \cdot \mathrm{H}_{2} \mathrm{O}$. \\
\hline
\end{tabular}


experiments were performed in duplicate with four replicates for each treatment.

Long term decoloration experiments were initiated by adding $5 \mathrm{~mL}$ wet volume of fungal biomass from 5 day old culture in liquid Kirk's medium without amaranth to $100 \mathrm{~mL}$ culture flasks containing various media. Experiments were started at $83 \mu \mathrm{M}$ amaranth which was replenished after complete decolorations occurred as often as required.

\section{Assays of decoloration and enzyme activities}

One $\mathrm{mL}$ samples were taken at each time point and immediately replaced with Kirk's medium containing no glucose or ammonia tartrate. Amaranth dye concentrations were determined spectrophotometrically at $523 \mathrm{~nm}$. An O.D. ${ }_{523}$ of 1.0 per $\mathrm{cm}$ corresponded to an amaranth concentration of $41.5 \mu \mathrm{M}$. MnP activity was measured by monitoring specific oxidation of $\mathrm{Mn}^{2+}$ to chelated $\mathrm{Mn}^{3+}$ (Wariishi et al. 1992). One unit (U) of activity equals $1 \mu \mathrm{mol} \mathrm{Mn}^{2+}$ oxidized per minute at $25^{\circ} \mathrm{C}$ and $\mathrm{pH} 4.5$. Laccase activity assays were performed by measuring the oxidation of $2,2^{\prime}$ azino-bis(3-ethylbenzthiazoline-6-sulfonic) acid (ABTS) at $420 \mathrm{~nm} \quad\left(\varepsilon_{420}=36,000 \mathrm{M}^{-1} \mathrm{~cm}^{-1}\right)$ (Johannes and Majcherczyk 2000). One unit (U) of activity equals $1 \mu \mathrm{mol}$ ABTS oxidized per minute at $25^{\circ} \mathrm{C}$ and $\mathrm{pH}$ 5.0. These assays contained $50 \mathrm{mM}$ sodium acetate buffer and $0.2 \mathrm{mM}$ ABTS. All assays were performed in quadruplicate using 96-well microtiter plates and measured with a Spectra Max Plus Spectrophotometer (Molecular Devices, Sunnyvale, CA). One direction ANOVA with a Tukey-Kramer HSD post hoc test was performed using JMP 10.0 software (SAS Incorporated, Toronto, Canada).

\section{Results}

\section{Effect of nutrition on decoloration on agar-solidified} media

The effect of medium composition on fungal abilities to decolor the azo-dye, amaranth in seven different species of white-rot fungi (Table 1) was tested on different variations of nutrient media (Table 2).

Decoloration abilities after 6 days growth on agar plates are presented in Table 3. After a lag of 3-4 days all species except for Trametes cotonea decolored amaranth. Complete dye decoloration occurred for Phlebia radiata on low $\mathrm{N}$ Kirk's with $\mathrm{Mn}$, and for Trametes meyenii, Trametes pubescens and Trametes multicolor on low N/low glucose Kirk's. Significantly, T. meyenii also decolored completely on full nutrient Kirk's medium.

\section{Decoloration studies in liquid cultures}

Seven species of white-rot fungi were grown in liquid medium containing amaranth for four days. Low-N Kirk's was chosen because most species (6 of 7) had substantial decoloration capabilities on agar-solidified medium of this composition (Table 3). All species began decoloration immediately (Figure 1). Phlebia radiata, Bjerkandera adusta, and $T$. cotonea decolored amaranth only slightly which may be attributed to sorption to biomass rather than by enzymatic degradation. This is corroborated by the lack of detectable $\mathrm{MnP}$ and laccase activities in these species (Figure 2). The remaining species did not absorb dye. Trametes multicolor and T. pubescens decolored the best and both were able to decolor a second addition of dye within a 24 hour period, with the rates of the 2nd decoloration being approximately double that of the first exposures. Trametes versicolor and $T$. meyenii were able to achieve approx. 94 and 77 percent decoloration within 24 hours, respectively.

Secreted laccase and $\mathrm{MnP}$ were detected for the four species that showed the highest decoloring abilities, with laccase as the main lignin modifying enzyme (Figure 2). Trametes pubescens had the most laccase activity, which was three times that of the next best laccase producing species, T. multicolor. Trametes pubescens also had the highest MnP production, which was twice that of $T$. multicolor. Enzyme activities for lignin peroxidase, versatile peroxidase and dye-decolorizing peroxidase were not detected under the culturing conditions employed.

Table 3 Decoloration of amaranth by white-rot fungi grown on agar-solidified media

\begin{tabular}{|c|c|c|c|c|c|c|}
\hline Species & Kirk's & LG Kirk's & HN Kirk's & LN Kirk's & LN/LG Kirk's & LN Kirk's + Mn \\
\hline B.adusta & + & ++ & - & ++ & ++ & +++ \\
\hline P.radiata & + & + & + & ++ & - & ++++ \\
\hline T.cotonea & - & - & - & - & - & - \\
\hline T.meyenii & ++++ & +++ & +++ & +++ & ++++ & ++ \\
\hline T.pubescens & ++ & +++ & +++ & +++ & ++++ & +++ \\
\hline T.multicolor & + & - & + & +++ & ++++ & ++ \\
\hline T.versicolor & + & - & + & +++ & +++ & +++ \\
\hline
\end{tabular}

L, low; $\mathrm{H}$, high; $\mathrm{G}$, glucose; $\mathrm{N}$, nitrogen; -, no decolouration; +, low decolouration; ++, intermediate decolouration; +++, strong decolouration; ++++, complete decolouration. Results were consistent over four independent experiments. 


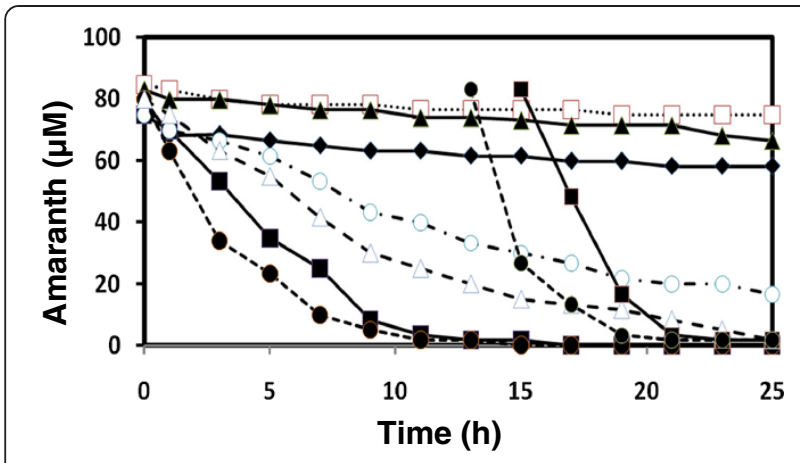

Figure 1 Amaranth decolouration by 9-day-old cultures in low-N Kirk's liquid medium. B. adusta ( $($ ), P. radiata $(\square), T$. cotonea

$(\mathbf{\Lambda})$, T. meyenii (o), T. pubescens $(\bullet)$, T. multicolor $(\mathbf{\bullet})$, T. versicolor $(\Delta)$. S.D. always less than $4 \%(n=5)$.

\section{Sequential decoloration experiments}

The four Trametes species that efficiently decolored amaranth dye in liquid medium were investigated to determine their respective most appropriate nutrient conditions for decoloration. A summary of these decoloration and enzyme activity characteristics are given in Table 4 .

The greatest number of repeat decolorations occurred with $T$. pubescens grown in low-N Kirk's, which was able to decolor 26 sequential daily additions of $83 \mu \mathrm{M}$ amaranth over a 29 day period. This species also had the highest level of laccase and MnP activities in this medium. The addition of $\mathrm{Mn}$ (II) or sufficient $\mathrm{N}$ resulted in 20 and 19 sequential decolorations, respectively, with reduced decoloration rates by day 20 in both. This decrease in decoloration rate was not reflected in measured enzyme activities which remained elevated (data not shown).

Trametes multicolor grown in low-N Kirk's was able to decolor 24 sequential additions of amaranth over 29 days. As with T. pubescens, this also corresponded to the highest levels of $\mathrm{MnP}$ and laccase activity in that species. The addition of $\mathrm{Mn}$ (II) decreased these enzymes' activities, and this was even more pronounced in normal Kirk's medium. After day 5 both laccase and MnP activities declined (data not presented). Despite this, decoloration rate was maintained until day 23 with most daily pigment additions being completely removed between 5 and 24 hours. This trend was most notable in low-N Kirk's, which was still able to decolor somewhat at day 29 despite there being very little measurable laccase or MnP activity.

Trametes versicolor also had its highest number of decolorations under low- $\mathrm{N}$ conditions, decoloring 20 sequential additions in 29 days. This also did not correspond to the highest activity of laccase and MnP. The highest enzyme activity was found in normal Kirk's medium, where only 9 sequential decolorations occurred. The addition of $200 \mu \mathrm{M} \mathrm{Mn}(\mathrm{II})$ to the medium doubled MnP but decreased laccase activity.
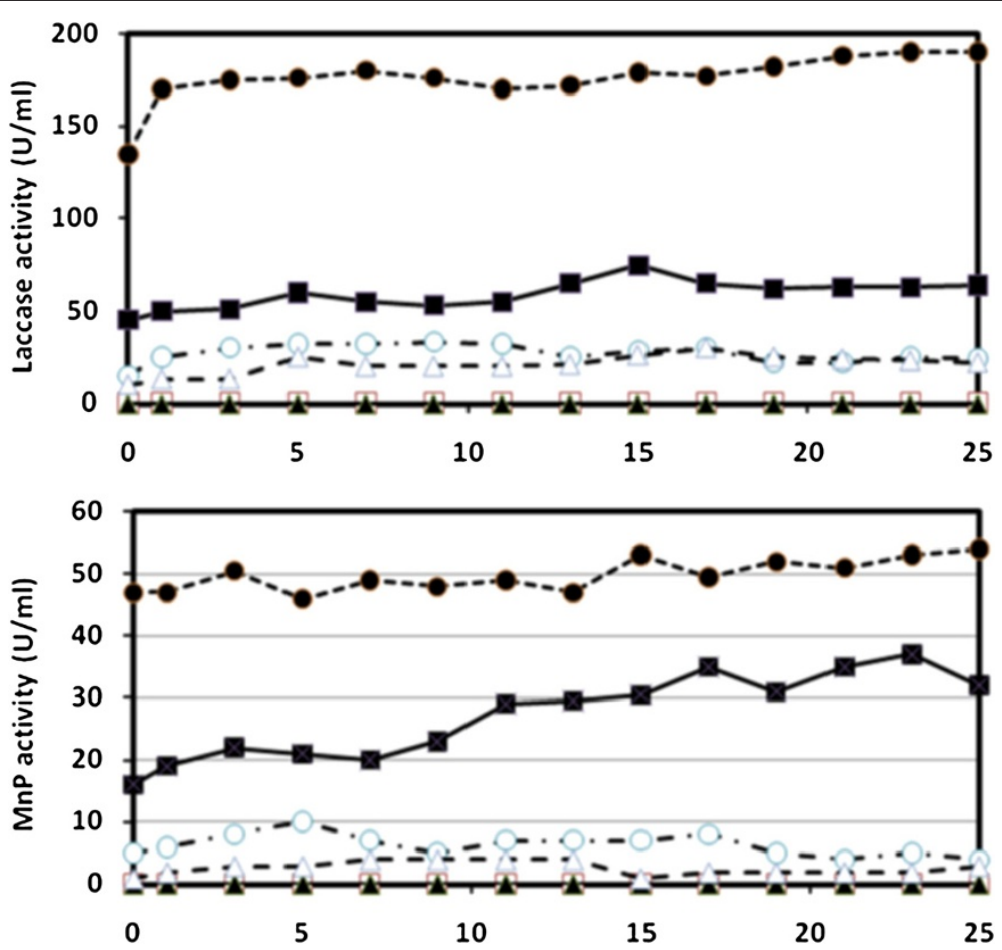

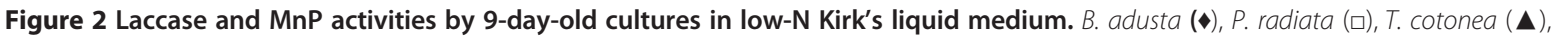
T. meyenii $(0)$, T. pubescens $(\bullet), T$. multicolor $(\mathbf{\bullet})$, T. versicolor $(\Delta)$. S.D. always less than $5 \%(n=5)$. B. adusta, P. radiata and T. cotonea all displayed negligible enzyme activities. 
Table 4 Decolouration and enzyme characteristics of Trametes species cultured in liquid media for 29 days

\begin{tabular}{|c|c|c|c|c|c|c|c|c|c|c|}
\hline & \multicolumn{4}{|l|}{ Decoloration } & \multicolumn{6}{|c|}{ Enzyme activities } \\
\hline & \multirow{2}{*}{$\begin{array}{l}\text { Initial } \\
\text { decoloration } \\
\text { period (days) }\end{array}$} & \multirow{2}{*}{$\begin{array}{l}\text { Number of } \\
\text { decolorations }\end{array}$} & \multirow{2}{*}{$\begin{array}{l}\text { Rate of } \\
\text { decoloration } \\
\text { at } 29 \text { days }\end{array}$} & \multirow{2}{*}{$\begin{array}{l}\text { Average } \\
\text { time for } \\
\text { decoloration } \\
\text { (days) }\end{array}$} & \multicolumn{3}{|c|}{ Mn Peroxidase } & \multicolumn{3}{|l|}{ Laccase } \\
\hline & & & & & $\begin{array}{l}\text { Maximum } \\
(\mathrm{U} / \mathrm{ml})\end{array}$ & $\begin{array}{l}\text { Day at } \\
\text { maximum }\end{array}$ & $\begin{array}{l}\text { Average } \\
\text { (U/ml) }\end{array}$ & $\begin{array}{l}\text { Maximum } \\
(\mathrm{U} / \mathrm{ml})\end{array}$ & $\begin{array}{l}\text { Day at } \\
\text { maximum }\end{array}$ & $\begin{array}{l}\text { Average } \\
(\mathrm{U} / \mathrm{ml})\end{array}$ \\
\hline \multicolumn{11}{|c|}{ Trametes versicolor } \\
\hline Kirks & 4 & 8 & Low & 2.75 & 18.2 & 15 & 8.0 & 90.5 & 8 & 55.0 \\
\hline $\begin{array}{l}\mathrm{LN} \\
\text { Kirks }\end{array}$ & 3 & 19 & Inter & 1.50 & 8.3 & 6 & 5.3 & 91.8 & 6 & 34.1 \\
\hline $\begin{array}{l}\text { LN Mn } \\
\text { Kirks }\end{array}$ & 3 & 16 & Low & 1.38 & 25 & 4 & 11.0 & 72.2 & 5 & 40.4 \\
\hline \multicolumn{11}{|c|}{ Trametes multicolor } \\
\hline Kirks & 3 & 21 & Inter & 1.29 & 22.5 & 4 & 11.1 & 84.1 & 6 & 42.7 \\
\hline $\begin{array}{l}\text { LN } \\
\text { Kirks }\end{array}$ & 3 & 24 & High & 1.25 & 38.9 & 5 & 6.5 & 87.4 & 5 & 40.2 \\
\hline $\begin{array}{l}\text { LN Mn } \\
\text { Kirks }\end{array}$ & 3 & 20 & Low & 1.10 & 50.0 & 5 & 18.3 & 84.6 & 6 & 35.0 \\
\hline \multicolumn{11}{|c|}{ Trametes pubescens } \\
\hline Kirks & 3 & 19 & Inter & 1.39 & 10.4 & 17 & 4.5 & 78.6 & 21 & 26.1 \\
\hline $\begin{array}{l}\text { LN } \\
\text { Kirks }\end{array}$ & 3 & 26 & High & 1.08 & 11.3 & 21 & 5.0 & 80.3 & 22 & 29.8 \\
\hline $\begin{array}{l}\text { LN Mn } \\
\text { Kirks }\end{array}$ & 3 & 20 & Low & 1.30 & 19.1 & 14 & 5.2 & 77.2 & 17 & 26.3 \\
\hline \multicolumn{11}{|c|}{ Trametes meyenii } \\
\hline Kirks & 4 & 23 & High & 1.26 & 20.5 & 15 & 7.3 & 88.1 & 17 & 31.5 \\
\hline $\begin{array}{l}\mathrm{LN} \\
\text { Kirks }\end{array}$ & 4 & 10 & inter & 2.91 & 20.8 & 6 & 4.8 & 86.7 & 8 & 39.6 \\
\hline $\begin{array}{l}\text { LN Mn } \\
\text { Kirks }\end{array}$ & 6 & 8 & Inter & 3.49 & 46.3 & 11 & 15.1 & 90.3 & 29 & 36.1 \\
\hline
\end{tabular}

Normal (Kirk's), low nitrogen (LN Kirk's), and low nitrogen supplemented with Mn (LN Mn Kirk's); for more details see Table 2. Each value is an average of five separate experiments. S.D. always less than $4 \%(n=5)$.

Trametes meyenii was the only species that had higher decoloration rates in the higher- $\mathrm{N}$ containing Kirk's medium. It decolored over twice as many sequential additions of amaranth in contrast to the low-N treatment. Both laccase and MnP activities were also highest for this condition. Even though the addition of $\mathrm{Mn}$ (II) to the low$\mathrm{N}$ culture medium doubled $\mathrm{MnP}$ activity in T. meyenii, there was no concomitant increase in decoloration rate. In fact, the initial lag phase took the longest in this condition, with 7 days to complete the first decoloration as opposed to 5 days for the Kirk's treatments.

\section{Decoloration in the presence of malonate}

Rates of decoloration increased significantly for all species of Trametes when $50 \mu \mathrm{M}$ sodium malonate was added to cultures that had been pretreated in low-N Kirk's (Figure 3). However, a comparison between species found no significant differences among the resultant rates of decoloration on a per fresh wt basis.

\section{Discussion}

The bioremediation of chemical contaminants requires the identification of appropriate species that are easily maintained in active condition. It is commonly accepted that stress conditions such as nutrient deprivation with their associated growth inhibition must elicit secondary metabolism before appropriate enzymes are activated in white-rot fungi (Archibald et al. 1997; Hatvani and Mécs 2002; Swamy and Ramsay 1999b; Kaal et al. 1995; Tatarko and Bumpus 1998; Tenuta and Lazarovits 2002). However, the provision of highly effective degradative processes by healthy and actively growing organisms would be more practical and efficaceous. This could also help to overcome the limited utility of fungal cultures for dye decolorization (Kokol et al. 2007).

Screening for effectiveness of dye decoloration on agarsolidified media indicated that $T$. cotonea had little activity and that of both B. adusta and P. radiata were much less effective than the four other tested Trametes species (Table 3). This might be attributed to the strategies of the 


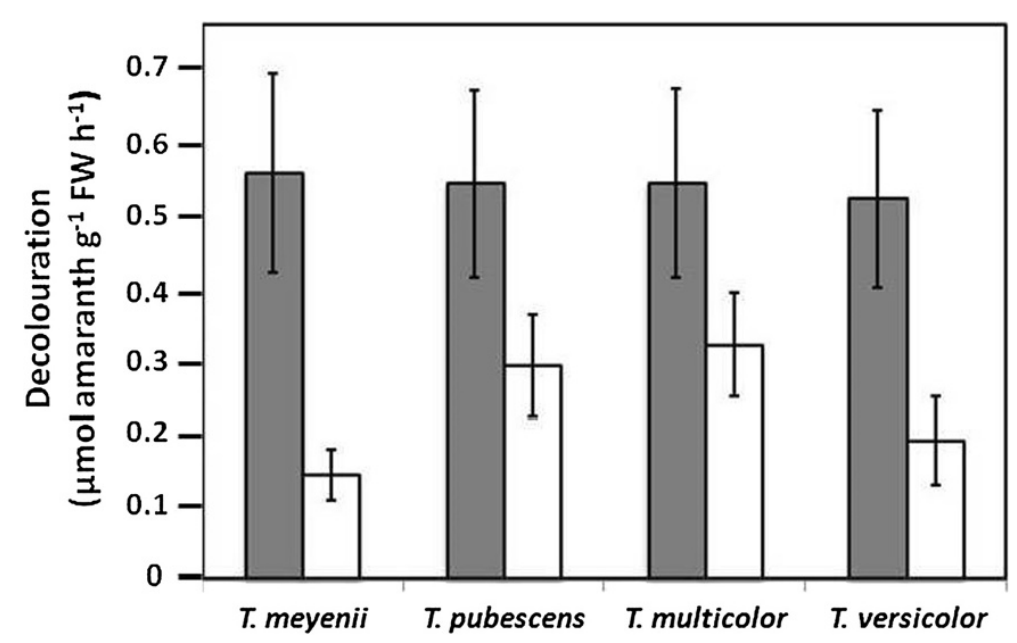

Figure 3 Rate of amaranth decolouration in the presence and absence of malonate by four Trametes species grown in low-N Kirk's. Presence and absence of $50 \mu \mathrm{M}$ sodium malonate. All values are means \pm S.D. $(n=5)$.

individual species with respect to natural substrate degradation (Barrasa et al. 2014). Furthermore, P. radiata, B. adusta, and $T$. cotonea decolored amaranth only slightly in liquid media through a process that involved sorption to their biomass (Figure 1). This was characterized by darkening of their mycelia with little or no secreted enzyme production (Figure 2). Results on agar-solidified media indicated that $P$. radiata and $B$. adusta are able to decolor amaranth and studies by other researchers using liquid culture have shown decoloration (Kaal et al. 1995; Robinson et al. 2001; Arora and Gill 2001). However, submerged cultures can display reduced decoloration because of low enzyme levels, and peroxidase activities are generally only optimal at high $\mathrm{O}_{2}$ tension. Laccase, on the other hand, can be enhanced at relatively low $\mathrm{O}_{2}$ (Wesenberg et al. 2003).

Trametes meyenii, T. pubescens and T. multicolor were equal to or better at decoloring amaranth than commonly employed T. versicolor. Of these, T. pubescens has been used to a limited extent in bioremediation of phenols (Ryan et al. 2005) and wine wastewater (Strong and Burgess 2007), and T. multicolor has been studied in the context of PCB degradation (Köller et al. 2000). Direct comparisons in decoloration and enzyme activites between these Trametes species has not been previously made.

Trametes meyenii had the highest rate of growth at $8 \%$ over the next best grower, T. multicolor, and was the only species to decolor best on normal Kirk's medium where it possessed prolonged activity. This supports an important role for laccase in the decoloration of amaranth by $T$. meyenii (Table 4). Laccase is produced during growth in T. versicolor, while peroxidases are produced during secondary metabolism (Wong and Yu 1999). Laccase production is also stimulated by low glucose (Tavares et al. 2005) and the presence of nitrogenous dye in this species (Casas et al. 2013), and dye degradation has been attributed solely to laccase in the white-rot fungus Datronis sp. (Vaithanomsat et al. 2010). The present study is the first to test dye decoloration and associated enzyme production in T. meyenii.

Liquid culturing more accurately reflects real wastewater treatment conditions. Low- $\mathrm{N}$ medium was tested initially because previous studies (Swamy and Ramsay 1999a; Swamy and Ramsay 1999b; de Jong et al. 1994) and our investigations with agar-solidified media showed that this enabled all species to decolor dye, with the exception of $T$. cotonea. Unlike the situations for the remaining Trametes species, $P$. radiata and $B$. adusta were severely affected by oxygen limiting conditions of liquid media. Trametes pubescens and T. multicolor were the most efficient and displayed the highest levels of secreted laccase and $\mathrm{MnP}$ activity in low-N media. However, there was not always a correlation between measured enzyme activities and a species' ability to decolor amaranth. High nitrogen has been previously shown to increase MnP (Kaal et al. 1995) and laccase production without increasing decoloration (Robinson et al. 2001). However, these other studies used very high ammonia that could cause stress in fungi (Tenuta and Lazarovits 2002), thereby invoking secondary metabolism.

The most efficient process from a bioremediation perspective would be if white-rot fungi were able to decolor consecutive additions of dye over an extended period of time. Therefore the four efficient Trametes species in this study were investigated further to determine their ability to decolor successive additions of the dye. The activities of laccase and $\mathrm{MnP}$ enzymes were monitored to determine their contributions to the degradative process because of their common occurence in white-rot fungi (Morgenstern et al. 2008; Wesenberg et al. 2003; Tomsovsky et al. 2009) 
and active roles in dye degradation under normal culture conditions, which does not appear to be the case for lignin peroxidase (Swamy and Ramsay 1999b).

Laccase and MnP were the only detected decolorizing enzymes in the culture media. With respect to lignin peroxidase, it is known that the culturing conditions used in the present study for Trametes fungi do not result in lignin peroxidase activity (Swamy and Ramsay 1999b). Furthermore, although DNA sequences for putative versatile and dye-decolorizing peroxidases exist in at least one of the fungal species of the presented study (Hofrichter et al. 2010; Ruiz-Dueñas et al. 2007), respective enzyme activities have yet to be demonstrated in this genus. For example, manganese-independent peroxidase (versatile peroxidase) was not detected in T. versicolor by Gavril et al. (2007). In addition, assaying for this enzyme (de Jong et al. 1992) and dye-decolorizing peroxidase (Sugano et al. 2006) did not detected any activity in the present study. The roles of laccase and $\mathrm{MnP}$ in the decoloration process is further supported by lag periods prior to decoloration corresponding to enzyme production in the culture media (Table 4). Once induced, degradation rates improved dramatically, with complete decoloration occurring in as little as 15 hours (Figure 1). However, dye decoloration by $T$. versicolor has been shown to be initially low regardless of the levels of measurable MnP and laccase (Swamy and Ramsay 1999b). This is supported by our findings that enzyme activities did not closely correspond to rate of decoloration (Table 4), thus indicating that other important factors are required for prolonged decoloration.

Despite $T$. versicolor having the highest measurable maximum and average laccase activities in long-term experiments, it was out performed by T. multicolor and $T$. pubescens in decoloration in low nitrogen. This could be in part because $\mathrm{MnP}$ activity was higher in T. multicolor, but that of T. pubescens was lower despite other research to the contrary (Strong and Burgess 2007). Trametes meyenii was exceptional because it possessed the longest period of rapid decoloration under higher nitrogen nutrition even though its enzyme activities were similar to those of T. versicolor and T. multicolor.

Supplying white-rot fungi with $\mathrm{Mn}(\mathrm{II})$ in low N Kirk's led to increases in measurable $\mathrm{MnP}$ production, but no improvement in long-term decoloration in all four Trametes species. This may indicate that either $\mathrm{MnP}$ is not the main decolorizing enzyme, or other necessary factors are more readily produced at low nitrogen.

It has been shown that despite high levels of extracellular enzymes, decoloration diminishs as glucose is depleted and is restored by its replenishment (Swamy and Ramsay 1999a). This could act as a general fixed carbon source required for the production of factors needed by the enzymes or more specifically, it could be a direct precursor of $\mathrm{H}_{2} \mathrm{O}_{2}$ via glucose-2-oxidase (Champagne and Ramsay 2005; Sen et al. 2012). We found that a relatively low concentration of malonate that would not be a significant source of carbon nutrition enhanced decoloration rates to the same magnitude on a per g FW basis in all four Trametes species when they were grown in low-N Kirk's medium (Figure 3). Manganese peroxidase oxidizes $\mathrm{Mn}^{2+}$ to $\mathrm{Mn}^{3+}$ which because of its instability, must chelate with an organic compound such as malonate (Schlosser and Hofer 2002; Kersten and Cullen 2007; Lundell et al. 2010; Liu et al. 2011). These chelators can act as low-molecular mass mediators (Higuchi 2004) that react with each other to eventually form peroxyl radicals (Gianfreda et al. 1999) able to attack a wide range of compounds non-specifically (Wariishi et al. 1988; Kuan and Tien 1993; Watanabe et al. 2000).

White-rot fungal species respond to nutrient conditions indicative of their specific ecological niches (Lundell et al. 2010; Tuor et al. 1995; Hiscox et al. 2010). This is the first study to show the dye decoloration potential of $T$. meyenii, T. pubescens, and T. multicolor. All three of these species possessed a strong capacity for prolonged dye decoloration by comparison with the more commonly studied $T$. versicolor. Enzyme activity for both laccase and MnP occurred over the decolorizing periods in all of these species. However, it appears that manganic chelation limited the degradative process and that the most efficient conditions for any given species may be that which enables the organisms to adequately produce chelating compounds. Studies with $T$. meyenii may help provide insight into the chelation phenomena because unlike other species it functions best when provided with full nutrient medium, a condition conducive to high metabolite production. In addition, more needs to be understood about the relative importance of secreted laccase and MnP enzymes. In some species of fungi, laccase and $\mathrm{MnP}$ have been shown to have an indirect interactive effect that enhances lignin depolymerization many times over that of individual enzymes, because of the production of $\mathrm{H}_{2} \mathrm{O}_{2}$ by laccase as a result of the oxidation of $\mathrm{Mn}^{2+}$ (Galliano et al. 1991; Leonowicz et al. 1999; 2001). However, the contribution of laccase and $\mathrm{MnP}$ to amaranth decoloration appeared to be only additive in $T$. versicolor with $\mathrm{MnP}$ providing considerably more to the decoloration process (Champagne and Ramsay 2005). It remains to be seen if this is the case for the other species of Trametes utilized in this study.

Of all the species tested, T. meyenii showed the most promise for industrial application purposes even though T. multicolor and T. pubescens functioned well in low- $\mathrm{N}$ medium. This is because T. meyenii possesses an elevated ability to decolor in higher- $\mathrm{N}$ environments, and most textile wastewaters contain relatively high levels of nitrogen, in part because of the nitrogenous structure of 
many dyes. This capacity to continue to simultaneously decolor dye over prolonged periods while growing in relatively nutrient-rich medium appears to be unique amongst white-rot fungi. The ecological significance of an ability to maintain lignolytic activity during higher nutritional states is also noteworthy.

\section{Competing interests}

The authors declare that they have no competing interests.

\section{Authors' contributions}

PRC designed and performed decoloration and enzyme assays and helped draft the manuscript. NL designed and undertook decoloration studies in the presence of chelators. DDL conceived and designed the study, supervised the research group, provided funding support, drafted and revised the manuscript. All authors approved the final manuscript.

\section{Acknowledgements}

This work was supported by the Natural Sciences and Engineering Research Council of Canada and the Advisory Committee of Queen's University, Canada

Received: 17 September 2014 Accepted: 23 September 2014

\section{Published online: 30 September 2014}

\section{References}

Archibald F, Bourbonnais R, Jurasek L, Paice M, Reid I (1997) Kraft pulp bleaching and delignification by Trametes versicolor. J Biotechnol 53:215-236

Arora D, Gill P (2001) Effects of various media and supplements on laccase production by some white rot fungi. Bioresour Technol 77:89-91

Barrasa JM, Blanco MN, Esteve-Raventós F, Altés A, Checa J, Martínez AT, Ruiz-Dueñas FJ (2014) Wood and humus decay strategies by white-rot basidiomycetes correlate with two different dye decolourization and enzyme secretion patterns on agar plates. Fungal Genet Biol, doi: 10.1016/j.fgb.2014.03.007

Casas N, Blánquez P, Vicent T, Sarrà M (2013) Laccase production by Trametes versicolor under limited-growth conditions using dyes as inducers. Environ Technol 34:113-119

Chagas EP, Durrant LR (2001) Decolourization of azo dyes by Phanerochaete chrysosporium and Pleurotus sajorcaju. Enzyme Microb Technol 29:473-477

Champagne P, Ramsay J (2005) Contribution of manganese peroxidase and laccase to dye decolouration by Trametes versicolor. Appl Microbiol Biotechnol 69:276-285

Dafale N, Wate S, Meshram S, Neti N (2010) Bioremediation of wastewater containing azo dyes through sequential anaerobic-aerobic bioreactor system and its biodiversity. Env Rev 18:21

de Jong E, Field J, de Bont J (1992) Evidence for a new extracellular peroxidase. Manganese-inhibited peroxidase from white-rot fungus Bjerkandera sp. BOS 55. FEBS Lett 299:107-110

de Jong E, Field J, de Bont J (1994) Aryl alcohols in the physiology of ligninolytic fungi. FEMS Microbiol Rev 13:153-187

Evans CS, Hedger JN (2001) Degradation of plant cell wall polymers. In: Gadd GM (ed) Fungi in bioremediation. Cambridge University Press, Cambridge, UK, pp 1-25

Galliano H, Gas G, Seris J, Boudet A (1991) Lignin degradation by Rigidoporus lignosus involves synergistic action of two oxidizing enzymes: Mn peroxidase and laccase. Enzyme Microb Technol 13:478-482

Gavril M, Hodson PV, McLellan J (2007) Decoloration of Amaranth by the white-rot fungus Trametes versicolor. Part 1. Statistical analysis. Can J Microbiol 53:313-326

Gianfreda L, Xu F, Bollag J (1999) Laccases: A useful group of oxidoreductive enzymes. Biorem J 3:1-26

Hatvani N, Mécs I (2002) Effect of the nutrient composition on dye decolourisation and extracellular enzyme production by Lentinus edodes on solid medium. Enzyme Microb Technol 30:381-386

Heinfling A, Martinez MJ, Martinez AT, Bergbauer M, Szewzyk U (1998a) Transformation of industrial dyes by manganese peroxidases from Bjerkandera adusta and Pleurotus eryngii in a manganese-independent reaction. Appl Environ Microbiol 64:2788-2793

Heinfling A, Martínez MJ, Martínez AT, Bergbauer M, Szewzyk U (1998b) Purification and characterization of peroxidases from the dye-decolourizing fungus Bjerkandera adusta. FEMS Microbiol Lett 165:43-50
Hessel C, Allegre C, Maisseu M, Charbit F, Moulin P (2007) Guidelines and legislation for dye house effluents. J Environ Manage 83:171-180

Higuchi T (2004) Microbial degradation of lignin: Role of lignin peroxidase, manganese peroxidase, and laccase. Proc Japan Acad Ser B Phys Biol Sci 80:204-214

Hiscox J, Baldrian P, Rogers H, Boddy L (2010) Changes in oxidative enzyme activity during interspecific mycelial interactions involving the white-rot fungus Trametes versicolor. Fungal Genet Biol 47:562-571

Hofrichter M, Ullrich R, Pecyna MJ, Liers C, Lundell T (2010) New and classic families of secreted fungal heme peroxidases. Applied Microbiol Biotechnol 87:871-897

Johannes C, Majcherczyk A (2000) Laccase activity tests and laccase inhibitors. J Biotechnol 78:193-199

Kaal E, Field J, Joyce T (1995) Increasing ligninolytic enzyme activities in several white-rot basidiomycetes by nitrogen-sufficient media. Bioresour Technol 53:133-139

Kersten P, Cullen D (2007) Extracellular oxidative systems of the lignin-degrading Basidiomycete Phanerochaete chrysosporium. Fungal Genet Biol 44:77-87

Kirk T, Fenn P (1982) Formation and action of the ligninolytic system in Basidiomycetes. In: Frankland JC, Hedger JN, Swift MJ (eds) Decomposer Basidiomycetes: their Biology and Ecology. Cambridge University Press, Cambridge, UK, pp 67-90

Kirk P, Cannon P, Minter D, Stalpers J (2009) Dictionary of the Fungi. Mycol Res 113:908-910

Kokol V, Doliska A, Eichlerova I, Baldrian P, Nerud F (2007) Decolourization of textile dyes by whole cultures of Ischnoderma resinosum and by purified laccase and Mn-peroxidase. Enzyme Microb Technol 40:1673-1677

Köller G, Möder M, Czihal K (2000) Peroxidative degradation of selected PCB: a mechanistic study. Chemosphere 41:1827-1834

Kuan I, Tien M (1993) Stimulation of Mn peroxidase activity: a possible role for oxalate in lignin biodegradation. Proc Natl Acad Sci U S A 90:1242-1246

Leonowicz A, Matuszewska A, Luterek J, Ziegenhagen D, Wojtas-Wasilewska M, Cho N, Hofrichter M, Rogalski J (1999) Biodegradation of lignin by white rot fungi. Fungal Genet Biol 27:175-185

Leonowicz A, Cho N, Luterek J, Wilkolazka A, Wojtas-Wasilewska M, Matuszewska A, Hofrichter M, Wesenberg D, Rogalski J (2001) Fungal laccase: properties and activity on lignin. J Basic Microbiol 41:185-227

Levin L, Forchiassin F, Ramos A (2002) Copper induction of lignin-modifying enzymes in the white-rot fungus Trametes trogii. Mycologia 94:377-383

Libra J, Borchert M, Banit S (2003) Competition strategies for the decolourization of a textile-reactive dye with the white-rot fungi Trametes versicolor under non-sterile conditions. Biotechnol Bioeng 82:736-744

Liu G, Zhou J, Wang J, Wang X, Jin R, Lv H (2011) Decolourization of azo dyes by Shewanella oneidensis MR-1 in the presence of humic acids. Appl Microbiol Biotechnol 91:417-424

Lundell T, Mäkelä M, Hildén K (2010) Lignin-modifying enzymes in filamentous basidiomycetes - ecological, functional and phylogenetic review. J Basic Microbiol 50:5-20

Martin G, Alibart O, Hierle R, Josse D, Baldi P, Zyss J (2012) Chemical safety in textile and apparel markets of emerging countries. Indian Textile J 122:118

Morgenstern I, Klopman S, Hibbett D (2008) Molecular evolution and diversity of lignin degrading heme peroxidases in the agaricomycetes. J Mol Evol 66:243-257

Nigam P, Armour G, Banat IM, Singh D, Marchant R (2000) Physical removal of textile dyes from effluents and solid-state fermentation of dye-adsorbed agricultural residues. Bioresour Technol 72:219-226

Pointing SB (2001) Feasibility of bioremediation by white-rot fungi. Appl Microbiol Biotechnol 57:20-33

Ramsay JA, Goode C (2004) Decolouration of a carpet dye effluent using Trametes versicolor. Biotechnol Lett 26:197-201

Reddy C, Mathew Z (2001) Bioremediation potential of white-rot fungi. In: Gadd GM (ed) Fungi in Bioremediation. Cambridge University Press, Cambridge, UK, pp 52-78

Robinson T, Chandran B, Nigam P (2001) Studies on the production of enzymes by white-rot fungi for the decolourisation of textile dyes. Enzyme Microb Technol 29:575-579

Ruiz-Dueñas FJ, Aguilar A, Martinez MJ, Zorn H, Martinez AT (2007) Gene cloning, heterologous expression, in vitro reconstitution and catalytic properties of a versatile peroxidase. Biocatal Biotransform 25:276-285

Ryan D, Leukes W, Burton S (2005) Fungal bioremediation of phenolic wastewaters in an airlift reactor. Biotechnol Prog 21:1068-1074 
Schlosser D, Hofer C (2002) Laccase-catalyzed oxidation of $\mathrm{Mn}^{2+}$ in the presence of natural $\mathrm{Mn}^{3+}$ chelators as a novel source of extracellular $\mathrm{H}_{2} \mathrm{O}_{2}$ production and its impact on manganese peroxidase. Appl Environ Microbiol 68:3514-3521

Sen K, Pakshirajan K, Santra S (2012) Modelling the biomass growth and enzyme secretion by the white rot fungus Phanerochaete chrysosporium in presence of a toxic pollutant. J Environ Protection 3:114-119

Strong P, Burgess J (2007) Bioremediation of a wine distillery wastewater using white rot fungi and the subsequent production of laccase. Water Sci Technol 56:179-186

Sugano Y, Matsushima Y, Shoda M (2006) Complete decolorization of the anthraquinone dye Reactive blue 5 by the concerted action of two peroxidases from Thanatephorus cucumeris Dec 1. Appl Microbiol Biotechnol 73:862-871

Swamy J, Ramsay JA (1999a) Effects of glucose and $\mathrm{NH}^{4+}$ concentrations on sequential dye decolouration by Trametes versicolor. Enzyme Microb Technol 25:278-284

Swamy J, Ramsay JA (1999b) Effects of $\mathrm{Mn}^{2+}$ and $\mathrm{NH}^{4+}$ concentrations on laccase and manganese peroxidase production and Amaranth decolouration by Trametes versicolor. Appl Microbiol Biotechnol 51:391-396

Tatarko M, Bumpus JA (1998) Biodegradation of congo red by Phanerochaete chrysosporium. Water Res 32:1713-1717

Tavares A, Coelho M, Coutinho J, Xavier A (2005) Laccase improvement in submerged cultivation: induced production and kinetic modelling. J Chem Technol Biotechnol 80:669-676

Tenuta M, Lazarovits G (2002) Ammonia and nitrous acid from nitrogenous amendments kill the microsclerotia of Verticillium dahliae. Phytopathol 92:255-264

Toh Y, Yen JJL, Obbard JP, Ting Y (2003) Decolourisation of azo dyes by white-rot fungi (WRF) isolated in Singapore. Enzyme Microb Technol 33:569-575

Tomsovsky M, Popelarova P, Baldrian P (2009) Production and regulation of lignocellulose-degrading enzymes of poria-like wood-inhabiting basidiomycetes. Folia Microbiol (Praha) 54:74-80

Tuor U, Winterhalter K, Fiechter A (1995) Enzymes of white-rot fungi involved in lignin degradation and ecological determinants for wood decay. J Biotechnol 41:1-17

Vaithanomsat P, Apiwatanapiwat W, Petchoy O, Chedchant J (2010) Production of ligninolytic enzymes by white-rot fungus Datronia sp. KAPI0039 and their application for reactive dye removal. Int J Chem Eng 2010:6, Article ID 162504

Van Aken B, Hofrichter M, Scheibner K, Hatakka A, Naveau H, Agathos S (1999) Transformation and mineralization of 2,4,6-trinitrotoluene (TNT) by manganese peroxidase from the white-rot basidiomycete Phlebia radiata. Biodegradation 10:83-91

Viswanath B, Rajesh B, Janardhan A, Kumar AP, Narasimha G (2014) Fungal laccases and their applications in bioremediation. Enzyme Res 2014:21, Article ID 163242

Wariishi H, Akileswaran L, Gold MH (1988) Manganese peroxidase from the basidiomycete Phanerochaete chrysosporium: spectral characterization of the oxidized states and the catalytic cycle. Biochem 27:5365-5370

Wariishi H, Valli K, Gold MH (1992) Manganese oxidation by manganese peroxidase from the basidiomycete Phanerochaete chrysosporium. J Biol Chem 267:23689-23695

Watanabe T, Katayama S, Enoki M, Honda Y, Kuwahara M (2000) Formation of acyl radical in lipid peroxidation of linoleic acid by manganese-dependent peroxidase from Ceriporiopsis subvermispora and Bjerkandera adusta. Eur J Biochem 267:4222-4231

Wesenberg D, Kyriakides I, Agathos S (2003) White-rot fungi and their enzymes for the treatment of industrial dye effluents. Biotechnol Adv 22:161-187

Wong Y, Yu J (1999) Laccase-catalyzed decolourization of synthetic dyes. Water Res 33:3512-3520

doi:10.1186/s13568-014-0074-3

Cite this article as: Chenaux et al.: Trametes meyenii possesses elevated dye degradation abilities under normal nutritional conditions compared to other white rot fungi. $A M B$ Express 2014 4:74.

\section{Submit your manuscript to a SpringerOpen ${ }^{\circ}$ journal and benefit from:}

- Convenient online submission

- Rigorous peer review

- Immediate publication on acceptance

- Open access: articles freely available online

- High visibility within the field

- Retaining the copyright to your article

Submit your next manuscript at $\gg$ springeropen.com 